\title{
Timing and nature of late Quaternary mountain glaciation
}

\author{
GLENN D. THACKRAY, ${ }^{*}$ LEWIS A. OWEN ${ }^{2}$ and CHAOLU YI \\ ${ }^{1}$ Department of Geosciences, Idaho State University, Pocatello, Idaho, USA \\ 2 Department of Geology, University of Cincinnati, Cincinnati, Ohio, USA \\ ${ }^{3}$ Institute of Tibetan Plateau Research, Chinese Academy of Sciences, Beijing, China
}

Thackray, G. D., Owen, L. A. and Yi, C. 2008. Timing and nature of late Quaternary mountain glaciation. J. Quaternary Sci., Vol. 23 pp. 503-508. ISSN 0267-8179.

Received 6 June 2008; Accepted 9 June 2008

\begin{abstract}
Compilations of regional- to subcontinental-scale mountain glacier chronologies from five continents, plus Hawaii, examine the temporal and spatial patterns of mountain glaciation. The compilations yield key insights into the nature of past fluctuations in temperature and precipitation in mountains and adjacent regions, and provide baseline data for examining the dynamics of glacier responses to climate change. Key insights from these compilations include the wide variability of glacier responses to fluctuations in insolation, temperature and precipitation and the regionally specific variations in climatic variables through late Quaternary time. The compilations highlight the need to improve the density and quality of geochronological data and to enhance the understanding of the links between climate and glaciation. Copyright (C) 2008 John Wiley \& Sons, Ltd.
\end{abstract}

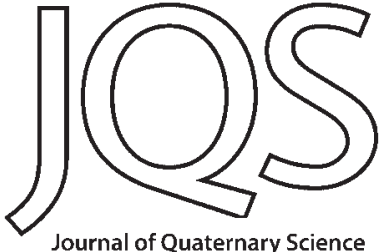

Journal of Quaternary Science

KEYWORDS: glaciation; mountains; climate change; geochronology; late Quaternary.

\section{Introduction}

Mountain glaciers and their deposits represent important archives of past climatic information. Mountain glaciers are highly sensitive to fluctuations in temperature and precipitation and, thus, the record of glacier growth and retreat defines those climatic variables. Data from widespread locales indicate that the timing of mountain glacier maxima and subsidiary advances varied widely, as first described on a global scale by Gillespie and Molnar (1995). That variability reflects important palaeoclimatic processes. In particular, mountain glaciation is influenced by regional, not global, climatic processes, and therefore mountain glacier fluctuations can be expected to vary strongly across the globe.

Indeed, numerous studies have demonstrated the complex variability of mountain glacier chronologies. Many mountain glacier systems, for example, reached their maximum Late Pleistocene positions around the time of the Northern Hemisphere ice sheet maximum, the global Last Glacial Maximum (LGM) centred on ca. $21 \mathrm{ka}$ (e.g. numerous chapters in Ehlers and Gibbard, 2004a,b,c). Conversely, other mountain glacier systems reached their maximum Late Pleistocene positions before the ice sheet maximum, in, for example, the tropical Andes (Smith et al., 2005), Tibet (Owen et al., 2003, 2005), Alaska, USA (Briner et al., 2005), Washington, USA (Thackray, 2001) and Mediterranean Europe (Hughes et al., 2006). Other mountain glacier systems reached their maximum

*Correspondence to: G. D. Thackray, Department of Geosciences, Idaho State University, Pocatello, ID 83201, USA.

E-mail: thacglen@isu.edu ice extent or near maximum extent after the $21 \mathrm{ka}$ BP ice sheet maximum, at, for example, Nanga Parbat, Pakistan (Phillips et al., 2000) and in parts of the northwestern United States (e.g., Licciardi et al., 2001; Thackray et al., 2004). Variations in precipitation delivery to glacier systems have often been cited as important influences on these 'asynchronous' fluctuations, and for some ice sheet synchronous advances as well (e.g. Shulmeister et al., 2005, in New Zealand). It is thus clear from many examples that considerable variability characterises the timing of mountain glacier fluctuations around the globe, and that a variety of palaeoclimatic processes are responsible for the variability. Thus, regional patterns of mountain glacier chronologies represent a relatively untapped opportunity to enhance understanding of palaeoclimatic processes.

As part of the INQUA's Palaeoclimate Commission (PALCOMM), Project 0407 (Timing and Nature of Mountain Glacier Advances, from 5e to $Y D$ ) was established in 2004 to examine this regional and global variability in Late Pleistocene mountain glacier fluctuations. Mountain glacier chronologies on five continents, plus Hawaii, were assessed by project members. The aim of these efforts was to review mountain glacier chronologies at the regional to continental scales, and to propose climatic interpretations for those glacier fluctuations. In so doing, the researchers have revealed temporal and spatial patterns of glaciation particular to each region of coverage. The pattern of ice fluctuations that emerges is globally complex, but potentially very meaningful in terms of our understanding of palaeoclimatic fluctuations.

The project group convened a workshop entitled Timing and Nature of Mountain Glaciation, from High Asia to the World: Exploring Aspects of Climate Change, Glaciation, and Landscape Evolution, held in September 2006, in Xining, China, and 
the Tibetan Plateau. The workshop hosted 62 participants from eight countries, featured 31 papers in oral and poster form, and included several discussion sessions that debated the implications of glacial chronologies and glacial impacts on landscape evolution in various climatic regimes. A five-day field excursion examined several field sites across the Tibetan Plateau where new chronologies have been produced.

The project and workshop have produced two edited journal issues. The first, entitled Mountain Glaciation and Landscape Evolution, is a special issue of Geomorphology, scheduled to appear in 2008 (Owen et al., 2008a). That special issue focuses on the impacts of mountain glaciation on landscape evolution. This issue of the Journal of Quaternary Science is the second and final one to result from the project and workshop.

The papers in this special issue take full advantage of the ongoing revolution in the dating of glacial sequences and associated landforms. Over the past ca. 15 years, methods such as cosmogenic radionuclide (CRN) surface exposure dating and optically and infrared-stimulated luminescence (OSL and IRSL) dating have come into widespread and aggressive use. Those applications have produced chronologies where none were previously possible, and have strengthened existing chronologies or expanded them to cover the entire span of the late Quaternary. Therein lies the unique contribution of this issue. Several previous efforts have compiled information on glacial extent and chronology (e.g. Gillespie et al., 2003; Ehlers and Gibbard, 2004a,b,c; the Snowline Database project, Mark et al., 2005). This compilation is unique in its focus on the entire late Quaternary. In approaching glacial chronologies spanning the late Quaternary, the members of Project 0407 have intended to shed light on the diversity of glacial chronologies and of climatic controls on ice fluctuations. In this paper, we summarise the key findings of Project 0407, and specifically the papers presented in this special issue.

\section{Context}

The papers presented in this issue cover mountain glacier records spanning five continents (Australasia and Antarctica excluded), plus Hawaii (Fig. 1). The geographic coverage, however, is neither uniform nor global. Rather, the coverage emphasises areas where robust new chronologies have been published and where new understanding has developed recently. As is clear in the following continental summaries, the results belie important mechanisms of mountain glacier responses to climatic fluctuations.

\section{Asia}

Three papers in this special issue address glaciation in Asia. These papers concentrate on the Himalayan-Tibetan orogen (Owen et al., 2008b; Yi et al., 2008), which constitutes the greatest concentration of glaciers outside the polar regions, and northeastern Russia (Stauch and Gualtieri, 2008), which has been an area of much contention.

Owen et al. (2008b) summarise chronologies in the Himalayan-Tibet orogen, focusing on recalculated CRN chronologies and presenting luminescence chronologies. They discern a variety of chronological patterns across the region. In the westernmost portions of the orogen, they find dominant advances ca. 75 and 20 ka, broadly correlative with Northern
Hemisphere ice sheet fluctuations. In the Transhimalaya/ western Tibet, monsoon-influenced Himalaya and monsooninfluenced Tibet, however, they find dominant advances during Marine Isotope Stage (MIS) 3, at ca. 45 and $30 \mathrm{ka}$, and late MIS 2 , between 16 and $10 \mathrm{ka}$. They argue that this variability results largely from contrasting moisture sources and contrasting influences of global LGM cooling. The authors also discuss the myriad complications in applying these chronological methods to glacial sequences across the broad region.

The Holocene glacial chronologies from Tibet are discussed in detail in $\mathrm{Yi}$ et al. (2008). These are mainly derived from extensive radiocarbon dating. Yi et al. (2008) identify one early Holocene glacial episode, ca. 8.8-9.4 ka BP, and two to three substages of middle Holocene glaciation between 5.5 and $1.4 \mathrm{ka}$ BP. During the Little Ice Age two to three prominent ice advances occurred, with the advances possibly occurring 200 600 a earlier in southern and eastern bordering mountain ranges than in northern bordering mountains. Glacial successions across Tibet require additional dating to discern those temporal and spatial patterns more fully and concretely, and mass balance and atmospheric circulation models may help to constrain climatic influences on the variability of glaciation across Tibet.

Stauch and Gualtieri (2008) describe glaciation in northeastern Russia, focusing on five relatively robust chronologies. In the eastern portion of this region, ice advances correlate broadly with Northern Hemisphere ice sheet chronologies and with other proxies in the circum-North Atlantic region. In the western portion of the region, however, the latest ice advance is dated to ca. $55 \mathrm{ka}$, and no global LGM-correlative advance has been identified. Two additional advances occurred early in the last glacial cycle. Generally, the eastern areas lack evidence of those earlier advances, except on the Chukotka Peninsula. Stauch and Gualtieri (2008) attribute these chronological contrasts to contrasting moisture sources. The eastern region received moisture directly from the North Pacific Ocean. Conversely, drier conditions prevailed in the more continental western region, which receives moisture from Atlantic sources.

\section{Europe}

This special issue illustrates the nature of mountain glaciation in Europe by considering studies from the Alps and from several mountain ranges around the Mediterranean, including the Cantabrian, Pyrenees, Pindus and Apennine ranges. The Alps provide robust chronologies for mid-latitude glaciation, while the locales around the Mediterranean provide a low-latitude assessment of glaciation and an east-west gradient.

The Late Pleistocene chronologies from the northern foreland of the European Alps are reviewed by Ivy-Ochs et al. (2008). Luminescence ages define early advances beyond the mountain front at ca. 100 and $70 \mathrm{ka}$, but the most extensive ice cover developed between 30 and $18 \mathrm{ka}$, broadly synchronous with the global LGM. Ice retreated rapidly from those maximum positions, with $80 \%$ of ice volume lost by $18 \mathrm{ka}$, and readvanced during two Lateglacial stades.

Hughes and Woodward's (2008) study of the Mediterranean region demonstrates that Late Pleistocene glacial maxima several thousand years prior to the global LGM. Other chronologies, based primarily on ${ }^{10} \mathrm{Be}$ dating of moraine boulder exposure ages from the Pyrenees and Kaçkar mountains, however, suggest a close correlation of local mountain glacier maxima with the global LGM. Hughes and Woodward (2008) suggest the early local mountain glacier 


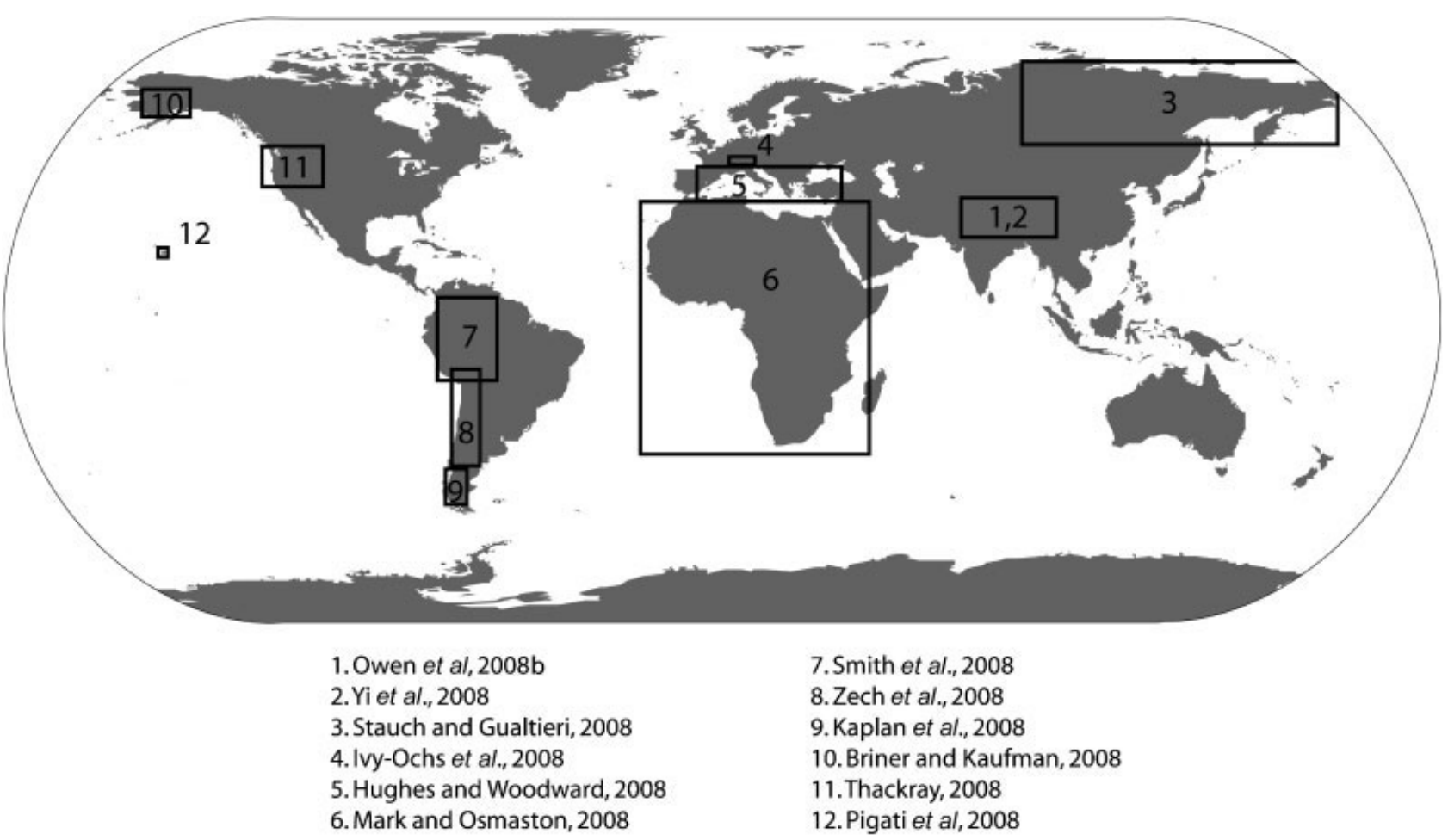

Figure 1 Map of location of studies included in this special issue and discussed in the text. Bounding boxes are approximate only

maximum is consistent with long palaeoecological records from the region, with the rapid ice build-up characteristic of the small mountain glaciers, and with models of southward diverted cyclonic tracks. They further infer that the global LGM-correlative chronologies are problematic because the global LGM was very dry in the region, and extreme temperature depression would have been required to drive glacier growth at that time. Interestingly, the contrasting chronological results in some ranges (e.g., the Pyrenees) reflect different dating methods. Those conflicting results require resolution if the true glacial and palaeoclimatic patterns are to be revealed.

Clearly, much remains to be learned concerning European mountain glaciation. Contrasting chronological patterns in the Alpine and Mediterranean ranges likely reveal important palaeoclimatic contrasts, and only with further chronological, palaeoecological and ice modelling studies will those patterns be fully revealed. The remaining questions suggest that European glacial sequences should provide fruitful research opportunities for many years to come.

\section{Africa}

Mountain glacier chronologies from ten major mountains and ranges in Africa are reviewed by Mark and Osmaston (2008). The chronological record of African glaciation remains quite limited, but patterns are emerging with new chronologies. Radiocarbon dates document a widespread synchronous advance around the global LGM. An extensive ${ }^{36} \mathrm{Cl}$ exposure age dataset from Mt Kilimanjaro and Mt Kenya define the ages of glaciation more clearly. Landforms from the earliest documented glaciation yielded ages of between 355 and $74 \mathrm{ka}$. The maximum Late Pleistocene glaciation is dated to 17$20 \mathrm{ka}$, while a statistically indistinguishable, less extensive ice advance is dated to $15.8-16.3 \mathrm{ka}$. At Mt Kenya, the oldest deposit, a till, is dated by palaeomagnetic methods to $>740 \mathrm{ka}$. ${ }^{36} \mathrm{Cl}$ exposure dates define the ages of two moraine successions to the Middle Pleistocene. Unfortunately, results for suspected global LGM moraines are equivocal, ranging from 28 to $10 \mathrm{ka}$, but without any distinct age cluster(s).

\section{South America}

Glacial chronologies for South America are reviewed for the length of the Andes from the tropics to the Straits of Magellan. Smith et al. (2008) concentrates on the glacial chronologies from the tropical Andes of Ecuador, Peru and Bolivia. They discern both regional and local variability in the temporal and spatial patterns of glaciation. In Peru, surface exposure dating indicates an early local LGM (ca. $30 \mathrm{ka}$ ) in some areas and a Lateglacial local maximum elsewhere. In Bolivia, timing of maximum advances varies between leeward and windward valleys. In Ecuador, radiocarbon chronologies define the ages of glaciation, but the timing of the local LGM and Lateglacial advances are controversial. Smith et al. (2008) suggest that the strong variability results from changes in Atlantic and Pacific moisture sources, the El Niño-Southern Oscillation and insolation.

Mountain glacial chronologies between $15^{\circ}$ and $40^{\circ} \mathrm{S}$ are examined by Zech et al. (2008). They recalculate numerous Andean CRN exposure ages and address the temporal patterns of glaciation. Contrasting chronological patterns are identified in four regions. In the tropical Andes the recalculated ages reveal timing of dominant Late Pleistocene advances ca. 25$22 \mathrm{ka}, \mathrm{ca} .15 \mathrm{ka}$ and ca. 13-11 ka. Zech et al. (2008) correlate those advances with temperature minima. Glaciers reached maximum or near maximum extent during the Lateglacial, synchronous with major lake highstands between the tropical 
Andes and as far south as $30^{\circ} \mathrm{S}$. Between $30^{\circ}$ and $40^{\circ} \mathrm{S}$, glaciers reached maximum extent well before the global LGM, ca. $35 \mathrm{ka}$, which Zech et al. (2008) attribute to a northerly shift of the westerly belt, followed by drier conditions and moisturelimited glaciers at the time of the global LGM. Finally, Zech et al. (2008) conclude that glaciers receive ample moisture at all times and reached maximum extent during the global LGM south of $40^{\circ} \mathrm{S}$. Zech et al. (2008) discuss uncertainties in cosmogenic exposure age calculations, and note that the apparent patterns require much additional research.

The mountain glacier chronologies for southern South America, around $45^{\circ} \mathrm{S}$, are reviewed by Kaplan et al. (2008). They show that glacial chronologies varied across the southern Andes. On the western flank of the Andes glaciers were more extensive during MIS 4 than during MIS 2, with the reversed pattern on the eastern flank. They note a general pattern of major glaciation in phase with the global LGM, but with possible regionally contrasting glacier responses to millennial-scale events between 17 and $10 \mathrm{ka}$. They note that the apparent variability may be due either to real climate/ glacial variability, or to methodological uncertainties, mainly in dating methods.

Notably, all these reviews overlap somewhat in their regional coverage, and do not agree in all cases with respect to timing of glacial maxima or controls on glaciation. As discussed in detail by Zech et al. (2008), CRN production rate scaling schemes vary significantly, particularly for low-latitude, high-elevation sites. For these and other reasons, uncertainties remain in the application of cosmogenic exposure methods to the dating of glacial sequences. Furthermore, as in many parts of the globe, relative influences of temperature and precipitation on glacial chronologies remain open to debate. Clearly, resolution of cosmogenic exposure age issues and of glacier-climate linkages are keys to improved understanding of Late Pleistocene palaeoclimatic patterns.

\section{North America}

Temporal and spatial patterns of glaciation in western North America are described by Briner and Kaufman (2008) and Thackray (2008).

Briner and Kaufman (2008) review key glacier chronologies from northern Alaska (Brooks Range), central Alaska (Alaska Range), and south-west Alaska (Ahklun Mountains). Cosmogenic exposure ages indicate maximum Late Pleistocene ice extent during MIS 4 or 3. Briner and Kaufman (2008) attribute limited ice extent during MIS 2, and recession from terminal positions ca. 27-25 ka in northern Alaska and ca. 22-19 ka in southern Alaska, to reduced precipitation. The reduced precipitation resulted from exposure of the Bering-Chukchi shelf during the MIS 2 sea-level lowstand. A Younger Dryassynchronous readvance is indicated by $12-11$ ka exposure ages in two ranges of central and southwestern Alaska.

Thackray (2008) reviews mountain glaciation variability and glacial chronologies on a transect from the northwestern to western interior United States. In the coastal Olympic Mountains, he shows that maximum ice extent was reached during MIS 4 and MIS 3, with ice extent during the global LGM significantly diminished by drier regional climates. Similarly, ice extent on the eastern flank of the Cascade Mountains was greater during MIS 5, 4 and 3 than during MIS 2. The timing of those earlier advances, however, varies between the two regions, occurring during insolation maxima in the Olympic Mountains and during insolation minima in the Cascade
Mountains just $250 \mathrm{~km}$ east of the coastline. Farther inland, maximum Late Pleistocene ice extent occurred during MIS 2, but with variable timing. In some ranges maximum ice extent was reached at the time of the global LGM, while maximum or near-maximum ice extent in those and other areas was reached 15-18 ka. Thackray (2008), Licciardi et al. (2001) and other workers attribute the detailed patterns of timing to the drying effects of an ice sheet anticyclone apparent in general circulation models, to variations in westerly atmospheric flow and to local precipitation effects of pluvial Lake Bonneville. Clearly, additional dating and modelling efforts will be required to constrain and understand those patterns more fully.

\section{Hawaii}

Hawaii provides one of the most interesting locations to examine mountain glaciation. It is essentially a palaeoclimatic lightning rod, sampling climate in the equatorial Pacific ocean. New ${ }^{36} \mathrm{Cl}$ chronologies from Mauna Kea, Hawaii, are assessed by Pigati et al. (2008). They document the development of two summit ice caps, of similar extent, during MIS 2, with glaciers retreating from terminal positions ca. 23 and $13 \mathrm{ka}$. The climatic factors influencing the two ice cap expansions, however, appear to be quite different. Using subtropical Pacific palaeotemperature proxies and glacier mass balance models, they suggest that the earlier ice cap formed during a wet and cold period, while the later ice cap formed during a warmer but yet wetter period. The warmer but wetter, later period of ice cap development appears to have been characterised by persistent La Niña-like conditions. Thus, it is clear that these tropical island ice caps can be influenced by cooling or by increased moisture, in turn driven by a variety of climatic influences.

\section{Conclusions}

Mountain glaciers respond in complex fashion to combinations of temperature, precipitation, ice dynamics and bed conditions (see discussion, for example, in Owen et al., 2008). Thus, detailed inferences of palaeoclimate from studies of extent and chronology can be fraught with pitfalls. The chronologies presented in these papers, however, reveal clear patterns of glacial chronology and extent spanning the Late Pleistocene, and the inferences at the broad temporal and spatial scales of study are insightful and robust.

The chronologies described herein demonstrate strong variability in mountain glacier chronologies across the globe. While chronologies in several areas demonstrate synchrony with Northern Hemisphere ice sheet fluctuations, with maximum ice extent at the time of the global LGM (19-23 cal. ka BP at chronozone level 1, or 18-24 cal. ka BP, at chronozone level 2 after Mix et al., 2001), that pattern appears to be the exception rather than the rule. Many ice systems reached maximum extent either before or after the ice sheet maximum, and demonstrate ice fluctuations spanning much of Late Pleistocene time.

While the studies presented in this special issue cover a wide variety of geographic and climatic settings there are several dominant themes:

1. Glacial systems have highly variable chronologies, especially when viewed across the entire late Quaternary. 
2. The late Quaternary pattern of glacial advances at any location depends upon the actual climatic fluctuations at that location and the mass balance characteristics of the glaciers.

3. Insolation variations are the primary driver of glacial fluctuations, but are linked to ice volume in multiple ways. To some degree, thinking in the field still points to cooling during the global LGM as a dominant driver of glacier fluctuations. Certainly that is true in some areas, but not in all areas. Insolation also influences the Asian monsoon, which strongly influences Himalayan-Tibetan glacial systems, and westerly flow strength, which appears important in some mid-latitude mountain ranges.

4. Despite vast improvements in our ability to date glacial sequences, much improvement is still needed. Zech et al. (2008) and Owen et al. (2008b), for example, provide discussions on scaling factors and their influence on CRN dating and interpretation for chronologies in the Andes and Himalayan-Tibetan orogen. Significant programmes in geochronology are underway that will help resolve many of the dating issues, for example, the US National Science Foundation's Cosmic-Ray Produced Nuclide Systematics on Earth Project (CRONUS). CRONUS is making headway on that issue and others, but cosmogenic chronologies will likely maintain substantial uncertainties (e.g. Balco et al., 2008).

5. The chronologies summarised herein show many climatic events, especially where the global LGM-correlative advance was diminished in extent. Examples include Tibet, western central Asia, South America, and portions of the northwestern United States.

6. Mountain glaciers are widely useful indicators of palaeoclimatic fluctuations. Their rapid response to climate change and widespread distribution make them ideal probes of past climates.

7. Understanding of mountain glaciers and palaeoclimate will be improved through further refinement of dating methods and their applications, and through improved understanding of linkages between insolation, spatially heterogeneous climatic responses, ice dynamics and glacial sedimentation processes.

In summary, although general statements can be made regarding the timing and extent of mountain glaciation, much more intensive study is needed on local and regional scales to elucidate the nature of mountain glaciation. Significant geographic gaps exist in robust global glacial chronologies, particularly in many of the mountain ranges in South America, Africa, Asia and Australasia.

Acknowledgements This paper is an outgrowth of discussions at a workshop on mountain glaciation that was held in Tibet during September 2006, sponsored by the US National Science Foundation (grant numbers OISE-0536909 and EAR-0640378), Natural Science Foundation of China, and the International Quaternary Union. We thank the participants in that workshop and the authors of the papers in this special issue for their insightful contributions.

\section{References}

Balco G, Stone JO, Lifton NA, Dunai TJ. 2008. A complete and easily accessible means of calculating surface exposure ages or erosion rates from ${ }^{10} \mathrm{Be}$ and ${ }^{26} \mathrm{Al}$ measurements. Quaternary Geochronology 3: $174-195$.
Briner JP, Kaufman DS. 2008. Late Pleistocene mountain glaciation in Alaska: key chronologies. Journal of Quaternary Science 23: 659670.

Briner JP, Kaufman DS, Manley WF, Finkel RC, Caffee MW. 2005. Cosmogenic exposure dating of late Pleistocene moraine stabilization in Alaska. Geological Society of America Bulletin 117: 1108-1120.

Ehlers J, Gibbard PL (eds). 2004a. Quaternary Glaciations: Extent and Chronology. Part I: Europe. Elsevier: Amsterdam.

Ehlers J, Gibbard PL (eds). 2004b. Quaternary Glaciations: Extent and Chronology. Part II: North America. Elsevier: Amsterdam.

Ehlers J, Gibbard PL (eds). 2004c. Quaternary Glaciations: Extent and Chronology. Part III: South America, Asia, Africa, Australia, Antarctica. Elsevier: Amsterdam.

Gillespie A, Molnar P. 1995. Asynchronous maximum advances of mountain and continental glaciers. Reviews of Geophysics 33: 311364.

Gillespie AR, Porter SC, Atwater BF (eds). 2003. The Quaternary Period in the United States. Developments in Quaternary Science, Vol. 1. Elsevier: Amsterdam.

Hughes PD, Woodward JC. 2008. Timing of glaciation in the Mediterranean mountains during the last cold stage. Journal of Quaternary Science 23: 575-588.

Hughes PD, Woodward JC, Gibbard PL. 2006. Glacial history of the Mediterranean mountains. Progress in Physical Geography 30: 334364.

Ivy-Ochs S, Kerschner H, Reuther A, Preusser F, Heine K, Maisch M, Kubik PW, Schlüchter C. 2008. Chronology of the last glacial cycle in the European Alps. Journal of Quaternary Science 23: 559-573.

Kaplan MR, Moreno PI, Rojas M. 2008. Glacial dynamics in southernmost South America during Marine Isotope Stage 5e to the Younger Dryas chron: a brief review with a focus on cosmogenic nuclide measurements. Journal of Quaternary Science 23: 649-658.

Licciardi JM, Clark PU, Brook EJ, Pierce KL, Kurz MD, Elmore D, Sharma P. 2001. Cosmogenic ${ }^{3} \mathrm{He}$ and ${ }^{10} \mathrm{Be}$ chronologies of the late Pinedale northern Yellowstone ice cap, Montana, USA. Geology 29: 10951098.

Mark BG, Osmaston HA. 2008. Quaternary glaciation in Africa: key chronologies and climatic implications. Journal of Quaternary Science 23: 589-608.

Mark BG, Harrison SP, Spessa A, New M, Evans DJA, Helmens KF. 2005. Tropical snowline changes at the Last Glacial Maximum: a global assessment. Quaternary International 138-139: 168-201.

Mix A, Bard E, Schneider R. 2001. Environmental processes of the ice age: land, oceans, glaciers (EPILOG). Quaternary Science Reviews 20: 627657.

Owen LA, Finkel RC, Ma H, Spencer JQ, Derbyshire E, Barnard PL, Caffee MW. 2003. Timing and style of late Quaternary glaciations in NE Tibet. Geological Society of America Bulletin 115: 1356-1364.

Owen LA, Finkel RC, Barnard PL, Haizhou M, Asahi K, Caffee MW, Derbyshire E. 2005. Climatic and topographic controls on the style and timing of late Quaternary glaciation throughout Tibet and the Himalaya defined by ${ }^{10} \mathrm{Be}$ cosmogenic radionuclide surface exposure dating. Quaternary Science Reviews 24: 1391-1411.

Owen LA, Thackray GD, Anderson RS, Briner J, Kaufman D, Roe G, Pfeffer W, Yi C. 2008a. Integrated mountain glacier research: current status, priorities and future prospects. Geomorphology (in press).

Owen LA, Caffee MW, Finkel RC, Seong YB. 2008b. Quaternary glaciation of the Himalayan-Tibetan orogen. Journal of Quaternary Science 23: 513-531.

Phillips WM, Sloan VF, Shroder JF, Sharma P, Clarke ML, Rendell HM. 2000. Asynchronous glaciation at Nanga Parbat, northwestern Himalaya Mountains, Pakistan. Geology 28: 431-434.

Pigati JS, Zreda M, Zweck C, Almasi PF, Elmore D, Sharp WD. 2008. Ages and inferred causes of Late Pleistocene glaciations on Mauna Kea, Hawai'i. Journal of Quaternary Science 23: 683-702.

Shulmeister JP, Fink D, Augustinus P. 2005. A cosmogenic nuclide chronology of the last glacial transition in North-West Nelson, New Zealand: new insights in Southern Hemisphere climate forcing during the last deglaciation. Earth and Planetary Science Letters 233: 455-466.

Smith JS, Mark BG, Rodbell DT. 2008. The timing and magnitude of mountain glaciation in the tropical Andes. Journal of Quaternary Science 23: 609-634. 
Smith JA, Seltzer GO, Farber DL, Rodbell DT, Finkel RC. 2005. Early local last glacial maximum in the tropical Andes. Science 308: 678-681.

Stauch G, Gualtieri L. 2008. Late Quaternary glaciations in northeastern Russia. Journal of Quaternary Science 23: 545-558.

Thackray GD. 2001. Extensive early and middle Wisconsin glaciation on the western Olympic Peninsula, Washington, and the variability of Pacific moisture delivery to the Pacific Northwest. Quaternary Research 55: 257-270.

Thackray GD. 2008. Varied climatic and topographic influences on Late Pleistocene mountain glaciation in the western United States. Journal of Quaternary Science 23: 671-681.
Thackray GD, Lundeen KA, Borgert JA. 2004. Latest Pleistocene alpine glacier advances in the Sawtooth Mountains, Idaho, USA: reflections of midlatitude moisture transport at the close of the last glaciation. Geology 32: 225-228.

Yi C, Chen H, Yang J, Liu B, Fu P, Liu K, Li S. 2008. Review of Holocene glacial chronologies based on radiocarbon dating in Tibet and its surrounding mountains. Journal of Quaternary Science 23: 533-543.

Zech R, May J-H, Kull C, Ilgner J, Kubik PW, Veit H. 2008. Timing of the late Quaternary glaciation in the Andes from $\sim 15$ to $40^{\circ} \mathrm{S}$. Journal of Quaternary Science 23: 635-647. 